\title{
Tintinnids and rotifers in a northern Mediterranean coastal lagoon. Structural diversity and function through biomass estimations
}

\author{
Thong Lam-Hoai*, Claude Rougier, Gérard Lasserre \\ Laboratoire d'Hydrobiologie - Unité Mixte de Recherche (UMR-CNRS 5556), Université de Montpellier II, Case 093. \\ Place E. Bataillon, F-34095 Montpellier Cedex 05, France
}

\begin{abstract}
Daily zooplankton samples were obtained from the Etang de Thau, France, a $70 \mathrm{~km}^{2}$ coastal lagoon of the northwestern Mediterranean Sea. The survey was monitored at 2 stations inside the lagoon and at 1 station on the seaside during 4 periods in 1994. The microzooplankton, towed with a $40 \mu \mathrm{m}$ mesh size net, included tintinnids, rotifers, anthozoan larvae, and crustacean and mollusk larvae. The tintinnids and rotifers have not been studied in the lagoon yet. Over all the sampling periods, their mean biomass represented between 26 and $45 \%$ of the net collected microzooplankton biomass, which was estimated by image analysis. Their biomass in the central part of the lagoon free of anthropic activity was close to the level observed at the nearby seaside. However, at the shellfish culture area, the occurrence of oysters and of epibiotic fauna resulted in a drastic biomass reduction of these taxocoenoses by a factor of 10 compared to values measured in the middle of the lagoon. Samples collected during the fall indicated well-developed tintinnid and rotifer populations in this season. Inside the lagoon these populations seemed to be already abundant in early spring (March and June samples). An ordination of taxa biomasses showed 2 main factors which might have contributed to the organization of the tintinnid and rotifer assemblages: the geographical position and the thermal period. The geographical position integrated the lagoon-sea water exchange. The thermal period reflected both the populations' development cycles and the environmental constraints. The resulting effects appeared in assemblages structured in a space and time gradient. The capacity of the tintinnids and rotifers to quickly colonise the habitat (reproduction modes, resistance forms) and to use a wide range of food resources (organic matter, bacteria, pico- and nanoplankton) likely enhances their ability to serve as trophic links between primary and secondary producers. Hence, their function in the lagoon ecosystem is not minor.
\end{abstract}

KEY WORDS: Net microzooplankton Biomass structures - Environmental impact - Image analysis . Mediterranean coastal lagoon

\section{INTRODUCTION}

Besides dependencies and interactions related to their location between land and sea, lagoons are subjected to internal and irregular variations, through which the biocoenosis may be submitted to abrupt and undamaged evolution (Amanieu \& Lasserre 1982). Thus they appear to be original entities compared to adjoining ecosystems. Tintinnids and rotifers were the 2 microzooplankton groups surveyed in the present

\footnotetext{
•E-mail: lamhoai@hyd.univ-montp2.fr
}

study in the Etang de Thau, France, a $70 \mathrm{~km}^{2}$ coastal lagoon of the northwestern Mediterranean Sea. They have never been studied on this site, and have often been absent from studies related to the marine or lagoon environments because collection was made with a mesh size greater than $100 \mu \mathrm{m}$. The summarised qualitative fauna observations of Mathias \& Tcherniakofsky (1932) and Mathias \& Euzet $(1951,1962)$ included 7 species of tintinnids (Tintinnopsis beroidea, T. campanula, Stenosemella ventricosa, Favella ehrenbergii, F. serrata, Petalotricha ampulla and Eutintinnus fraknoii) and 2 species of rotifers (Synchaeta neapolitana and S. triophtalma). More recent studies of the 
zooplankton (Lam-Hoai 1985, Jouffre 1989, Lam-Hoai \& Amanieu 1989) dealt only with the mesozooplankton. Contribution estimates of the populations to the Shannon's diversity index already allowed typical assemblages of the lagoon or of the coastal zone to be distinguished and populations with strong demographic outbursts or those that are dominant in biomass to be specified (Rougier \& Lam-Hoai in press). In the following work, we aim to provide an understanding of the biomass fluctuations of tintinnid and rotifer populations in space and time and to outline the structural diversity of these taxocoenoses. Determination of such features associated with the analysis of relationships between populations and environment helps to evaluate the function of microzooplankton in the ecosystem, complementing previous studies on the other zooplankton groups at this site.

\section{MATERIAL AND METHODS}

Zooplankton were collected at the Etang de Thau Stns $T$ and $Z$ and $M$ at the seaside (Fig. 1). Stn $T$ is situated in the central area ( $7 \mathrm{~m}$ depth), while $\mathrm{Stn} Z$ is in the middle of a shellfish culture area, near the NW bank of the lagoon (5 $\mathrm{m}$ depth), and not far from the Canaux de Sète (about $7 \mathrm{~m}$ depth) by which the essential water exchanges between the lagoon and the sea occur.

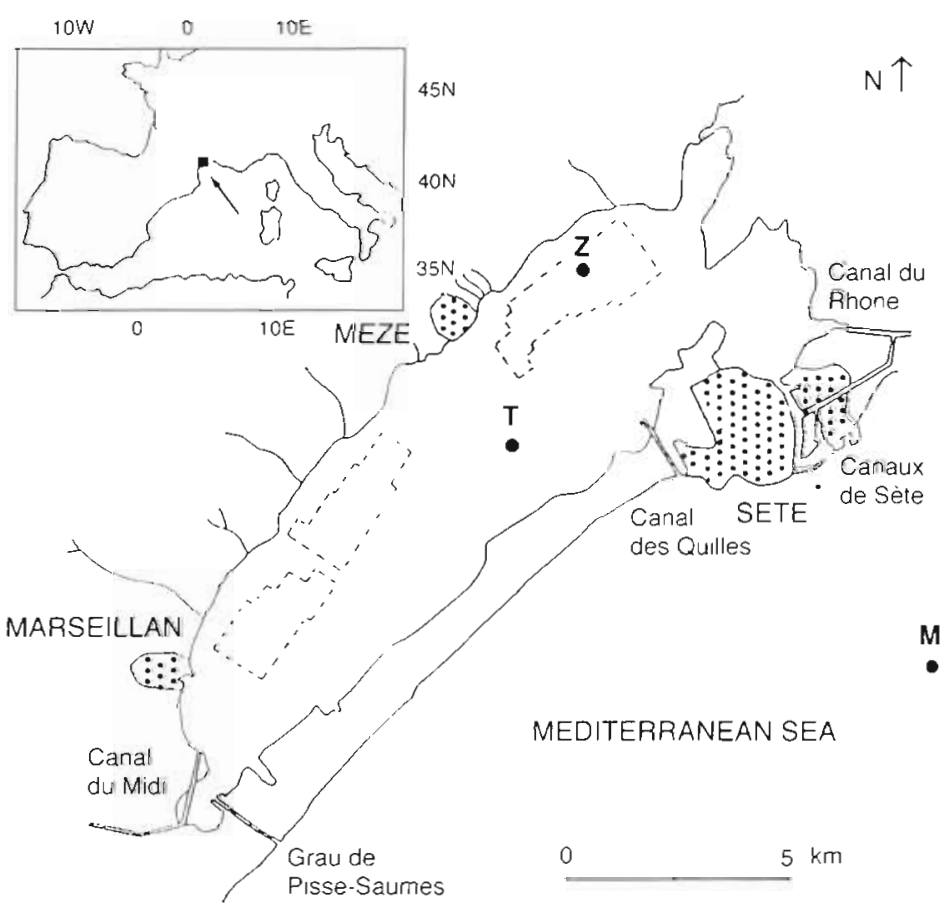

Fig. 1. Etang de Thau; broken line delimits the shellfish culture sectors The 3 sampling stations, $T, Z$ and $M$, were positioned inside and outside the lagoon
The survey was performed daily during 4 sampling periods in 1994. (1) from 21 to $25 \mathrm{March}$, (2) from 20 to 24 June, (3) from 26 to 30 September, and (4) from 28 November to 2 December. They corresponded roughly to the major events in the annual cycle of the oyster culture (growth, reproduction, post-breeding and pre-wintering periods). This $5 \mathrm{~d}$ replicating method may reduce the variation in the zooplankton catch. Each daily zooplankton sample was made up of 3 vertical tows at the station, from $2 \mathrm{~m}$ depth up to the surface, with a $40 \mu \mathrm{m}$ mesh size net and a $0.3 \mathrm{~m}$ diameter opening. Obviously, individuals less than $40 \mu \mathrm{m}$ and the fragile organisms (flagellates and aloricate oligotrichs) were not retained in the samples. The tintinnids (loricate oligotrichs) did not suffer any damage when captured by a plankton net. The plankton material was then fixed in a buffered $4 \%$ formol solution and slightly coloured with Rose Bengal to obtain the besi cuntrasted image in image analysis. An aqueous solution of $50 \%$ magnesium chloride was added to sub-samples $\left(1 \mathrm{~cm}^{3}\right.$ to about $\left.100 \mathrm{~cm}^{3}\right)$ before fixation in order to reduce the stress contraction of the organisms, such as aloricate rotifers, during identification.

Environmental conditions were recorded concurrently with the plankton sampling. Meteorological data were limited to the wind direction and force, which were recorded in situ by B. Bibent (pers. comm. 1995) with a digital data logger meteorological station. Water temperature $\left({ }^{\circ} \mathrm{C}\right)$ and salinity (psu) were measured with a WTW 196 salinometer coupled with a Tetracon $96 \mathrm{~T}$ sensor cell. From water samples, chlorophyll a concentration ( $\mathrm{g} \mathrm{I}^{-1}$ ) was determined by A. Vaquer (pers. comm. 1995), cellular concentrations (ind. $\mathrm{l}^{-1}$ ) of bacterioplankton, picophytoplankton and phytoplankton $>2 \mu \mathrm{m}$ were estimated by $\mathrm{C}$. Courties (pers. comm. 1995) through a flowcytometer. The multiple-species origin of chlorophyll data and the wide size range of phytoplankton prevented their use in further analyses.

Because of the extremely high density of some samples, they were separated into successive fractions (Folsom splitter) in order to facilitate sorting and to avoid cluttering in the numeration of organisms. Zooplankter count. measure of their size and estimation of their biomass in wet weight were made by an image analysis technique proposed by Lam-Hoai (1991j and Lam-Hoai \& Gril (1991). With this technique, a zooplankton individual viewed under the microscope appears as a silhouette, the form of which depends on the image contrast. This silhouette can be characterised by its perimeter and its surface, which 
define a specific form factor. To assess the third dimension of the object, a morphometric model which preserves the form factor of the organism, and therefore of its volume, was used. According to Mullin (1969) and Omori \& Ikeda (1984), if the specific weight of an animal is close to 1 , it is reasonable to establish the equivalence of its volume to its wet weight $\left(1 \mathrm{~cm}^{3} \approx 1 \mathrm{~g}\right)$. Density and wet biomass units were evaluated per cubic meter.

As the dimensions of the zooplankters depend on the different phases of their development, it is difficult to classify the individuals rationally into the size scale proposed by Dussart (1965). In the net sampled microzooplankton, the tintinnids' and rotifers' largest dimension in a few cases exceeded $300 \mu \mathrm{m}$. For convenience, crustacean nauplii, anthozoan and mollusk larvae were also classified into this category (Table 1). The other holoplankton and meroplankton organisms collected by the net were allocated to the mesozooplankton.

Identification of tintinnids (ciliates) is made by their lorica morphology, according to classifications of Jörgensen (1924), Kofoid \& Campbell (1939), Margalef \& Duran (1953) and Balech (1959). Nevertheless, LavalPeuto \& Brownlee (1986) underlined the great variability of this shell. For this reason, Tintinnopsis butschlii is considered as a phenotype of T. campanula (TCA in Table 1). Some tintinnids have not been identified to the specific level: Tintinnopsis sp. 2 (TS2) and Tintinnidium sp. (TIN). Favella spp. taxa (FAV) mainly includes $F$. serrata (Möb.) Jörgensen and sporadic individuals of F. ehrenbergii (Clap. \& Lachm.) Jörgensen. Rotifers, assimilated to ciliates in the beginning of the 18th century, are in fact very small metazoans (less than $1 \mathrm{~mm}$ ), and constitute a separate zoological embranchment. Classification criteria of Voigt (in Koste 1978), as well as these of Rousselet (1902), Remane (1929). Hollowday (1949), Berzins (1960), and Arndt et al. (1990), were used for rotifer identification. The majority of the species encountered during 1994 belonged to an aloricate group, the family of Synchaetidae.

Most of the population analyses were performed on tintinnid and rotifer biomass averaged over 5 sampling
Table 1 ldentified taxa, their identity codes, and their biomass percentages averaged over daily data during the 1994 survey at Stns $M, T$ and $Z$

\begin{tabular}{|c|c|c|c|c|}
\hline Taxon & Code & $M(\%)$ & $\mathrm{T}(\%)$ & $Z(\%)$ \\
\hline \multicolumn{5}{|l|}{ Tintinnids } \\
\hline Amphorides amphora (Cl.\& L) & AAM & 1.60 & & 0.01 \\
\hline Codonella acerca Jörg. & $\mathrm{CAC}$ & & 0.04 & 0.01 \\
\hline Codonella cratera (Leidy) & $\mathrm{CCR}$ & & 0.23 & 0.05 \\
\hline Codonella galea Hck. & CGA & 0.04 & & \\
\hline Codonellopsis morchella (Cl.) & $\mathrm{CMO}$ & 0.04 & & \\
\hline Codonellopsis orthoceros (Hck.) & COR & 0.01 & & \\
\hline Eutintinnus fraknoii Dad. & EFR & 0.08 & 0.02 & 0.10 \\
\hline Favella spp. & FAV & 5.07 & 12.39 & 4.22 \\
\hline Helicostomella subulata (Ehr.) & $\mathrm{HSU}$ & & 2.44 & 1.97 \\
\hline Metacytis mediterranea (Mereschk.) & MME & & 0.09 & 0.08 \\
\hline Parundella aculeata Jorg. & PAC & & 0.27 & 0.0003 \\
\hline Petalotricha ampulla (Fol) Kent & PAM & 0.003 & & \\
\hline Rhabdonella spiralis (Fol) & RSP & 0.14 & & 0.005 \\
\hline Salpingella acuminata (Cl. \& L.) & SAC & 0.01 & & \\
\hline Stenosemella ventricosa $(\mathrm{Cl} \& \mathrm{~L})$. & SVE & 0.28 & 0.07 & 0.35 \\
\hline Tintinnidium sp. & TIN & 0.33 & 0.13 & 0.33 \\
\hline Tintinnopsis beroidea (Stein) & TBE & & 0.15 & 0.03 \\
\hline Tintinnopsis campanula (Ehr.) & TCA & 4.69 & 0.03 & 0.17 \\
\hline Tintinnopsis corniger Hada & $\mathrm{TCO}$ & 0.01 & 16.08 & 6.91 \\
\hline Tintinnopsis cylindnca Daday & TCY & 0.03 & 0.16 & 0.04 \\
\hline Tintinnopsis sp.2 & TS2 & 1.27 & & 0.02 \\
\hline \multicolumn{5}{|l|}{ Rotifers } \\
\hline Brachionus plicatihs (Muller) & BRA & & & 0.01 \\
\hline Colurella colurus (Ehr.) & $\mathrm{CCO}$ & & & 0.001 \\
\hline Synchaeta baltica Ehr. & $\mathrm{SBA}$ & 0.01 & 10.26 & 7.67 \\
\hline Synchaeta cecilia Rousselet & $\mathrm{SCE}$ & & 0.22 & 0.11 \\
\hline Synchaeta grimpel Remane & SGR & 0.02 & & \\
\hline Synchaeta neapolitana Rousselet & SNE & 1.35 & 0.22 & 0.14 \\
\hline Synchaeta triophtalma Lauterborn. & STR & 15.46 & 1.10 & 3.04 \\
\hline Synchaeta vorax Rousselet & SVO & 4.42 & 0.80 & 0.61 \\
\hline Testudinella sp. & TES & 0.001 & & \\
\hline Trichocerca marina (Daday) & TMA & 0.07 & 0.11 & 0.11 \\
\hline \multicolumn{5}{|l|}{ Other microzooplankton groups } \\
\hline Anthozoan larvae & ANT & 0.05 & & \\
\hline Cirripeda nauplii & $\mathrm{CIR}$ & 0.68 & 19.67 & 9.03 \\
\hline Copepoda Calanoida nauplii & CAL & 13.47 & 6.25 & 10.51 \\
\hline Copepoda Cyclopoida nauplii & CYC & 22.89 & 3.90 & 7.89 \\
\hline Copepoda Harpacticoida nauplii & HAR & 21.09 & 2.89 & 13.90 \\
\hline Euphausiacea nauplii & EUP & 3.35 & & 0.02 \\
\hline Gasteropoda larvae & GAS & 0.11 & 8.09 & 8.79 \\
\hline Lamellibranchia larvae & LAM & 3.45 & 14.40 & 23.90 \\
\hline
\end{tabular}

days. Differences in biomass between sites or stations and their evolution during the survey were recognised using frequency diagrams. Population organisation trends were assessed with a factorial correspondence analysis (FCA) of these biomasses. Pearson's correlation coefficient $\mathrm{r}$ was computed from daily biomasses over the whole survey on the one hand between each taxonomic group $(Y$ ) and each environmental variable $(X)$, and on the other hand between taxa ( $Y$ and $X$ ). This coefficient measured the probable connection or dependence between $Y$ and $X$, thus allowing interpretation of relationships between populations and environment and of assemblage structures. It is signifi- 
cantly different from zero when its absolute value is larger than the one given by the Fisher \& Yates tables (2-tailed test) for $n-2$ degrees of freedom, and for a given error probability (Klugh 1970), n being the number of data couples used to define r. For practical purpose, only correlations calculated from at least 10 couples of data and having an error probability equal or less than 0.05 in a bilateral test were retained as significant. In some cases, microscopic preparations were necessary in order to specify the type of relationship existing between the populations.

\section{RESULTS}

During the 1994 survey in the central part of the Etang de Thau (Stn T), the overall biomasses of tintinnids and rotifers were estimated as high as $20.41 \%$ of the net zooplankion totai biomass and $44.8 \%$ of the net microzooplankton biomass. Comparable counts of tintinnids larger than $40 \mu \mathrm{m}$, taken from bottle samples as well as from net samples, showed an estimated abundance of up to $1 \%$ of the total ciliate density at Stn $\mathrm{M}$ and between 6 and $17 \%$ at Stn $\mathrm{T}$. The fraction that escaped from the net collections was mostly aloricate oligotrichs in the 10 to $60 \mu \mathrm{m}$ size range (modal size: 20 to $30 \mu \mathrm{m}$ ). The remaining fraction was composed of tintinnids, loricate oligotrichs that could be of the magnitude of the copepod biomass (e.g. Stn T, June 1994).

Among the 40 taxa identified in the whole microzooplankton net collection, 21 tintinnid and 10 rotifer taxa are listed in Table 1. The tintinnid specific richness (taxa number) in the central lagoon Stn $\mathrm{T}$ was slightly inferior to the one from the seaside Stn M (13 vs 15). A contrario, the marine station counted 7 rotifer species vs 8 found in the lagoon. Populations originating in coastal waters were sometimes found at shellfish culture Stn $Z$. These taxocoenoses lived in an environment under physical constraints and influenced by forcing factors.

\section{Environment and forcing factors}

Hydrodynamics in the Etang de Thau are known to be linked with meteorological conditions, especially with the wind regime (Lam-Hoai \& Amanieu 1989) Within the usual tidal range (maximum amplitude 0.05 to $0.07 \mathrm{~m}$ ), most of the water exchanges between the lagoon and the sea occur through the Canaux de Sète because of their large size ( $7 \mathrm{~m}$ depth and $44 \mathrm{~m}$ width). Hydrodynamic modelling from Millet (1989) showed that in periods of S-SE winds, the area surrounding Stn $Z$ facing these channels could have been influ- enced by these displaced water masses. During the 1994 survey, prevailing E-SE winds in September and in November-December were associated with cloud cover (barometric depression). Their direction and their duration forced a fraction of the waters from the Rhone Delta $(100 \mathrm{~km}$ to the east) to move westward along the coast. These events induced a drop in the local salinity, particularly conspicuous at Stn $M$ by September (from values of 36-37.5 to values as low as $30-34$ ). In such meteorological conditions, the suitable orientation of the lagoon inlets reinforced the coastal water input, which was detected at Stn Z.

During the survey, the water temperature varied between 12.7 and $23.2^{\circ} \mathrm{C}$ in the lagoon with a maximum-minimum difference of $10.5^{\circ} \mathrm{C}$. At the seaside, this difference in the range $\left(11.8\right.$ to $\left.20.2^{\circ} \mathrm{C}\right)$ was more attenuated. The salinity in the sea remained close to 37 , except during the period of dilution by the waters coming from the Rhone Dclta. In the lagoon, salinities, from low values in March (31.5-32.2) and in November-December (30.5-31.5), were raised by evaporation to $35.9-36.5$ in June and to $36.9-37.9$ in September. Relationships between these environmental parameters and zooplankton populations will be analysed in a later section of this study.

\section{Variations of tintinnids' and rotifers' overall biomasses in space and time}

Highest recorded taxa biomasses were about $19000 \mu \mathrm{g} \mathrm{m}^{-3}$ (average $5200 \mu \mathrm{g} \mathrm{m}^{-3}$ ) for the tintinnids and $12000 \mathrm{\mu g} \mathrm{m}^{-3}$ (average $2240 \mu \mathrm{g} \mathrm{m}^{-3}$ ) for the rotifers, while rare taxa did not exceed $50 \mu \mathrm{g} \mathrm{m}^{-3}$ for the former group and $10 \mu \mathrm{g} \mathrm{m} \mathrm{m}^{-3}$ for the latter. The overall biomass of the taxocoenoses fluctuated from one station to another and also according to the sampling periods: 2 to $48 \%$ of the net microzooplankton biomass at the seaside (Stn M), 27 to $68 \%$ in the lagoon central area (Stn T) and 20 to $39 \%$ in the shellfish culture zone (Stn Z). Characteristic differences are shown in a sector diagram (Fig. 2).

At the coastal Stn M, tintinnid and rotifer biomasses, which were very low in March and in June (maximum $1810 \mu \mathrm{g} \mathrm{m}^{-3}$ ), increased 10 -fold in September $(19997 \mu \mathrm{g}$ $\mathrm{m}^{-3}$ ). This increase was mainly due to the development of the rotifer Synchaeta triophtalma (with more than 40 ind. $\mathrm{l}^{-1}$ ), which had the highest mean biomass of all the rotifers collected in 1994. The conditions encountered at Stn $M$ in September were rather unusual, being marked by a consistent drop of the salinity (averaged values: 33.1 at Stn $M$ compared to 37.7 in the lagoon). Coastal water dilution in this period could be due to the Rhône River flows driven towards the Etang de Thau as previously mentioned. This situation would 
Fig. 2. Biomasses of tintinnids (grey area), rotifers (dark area) and other net microzooplankton (blank area) in proportion to the overall net microzooplankton mean biomass (number in the bottom-left corner of each box, in $\mu \mathrm{g} \mathrm{m}^{-3}$ ) which is shown by the size of the sector diagrams. Some diagrams have had to be magnified (magnification shown). Codes of tintinnid and rotifer dominant populations are plotted adjacent to the corresponding sectors (see Table 1 for explanation of identity codes)

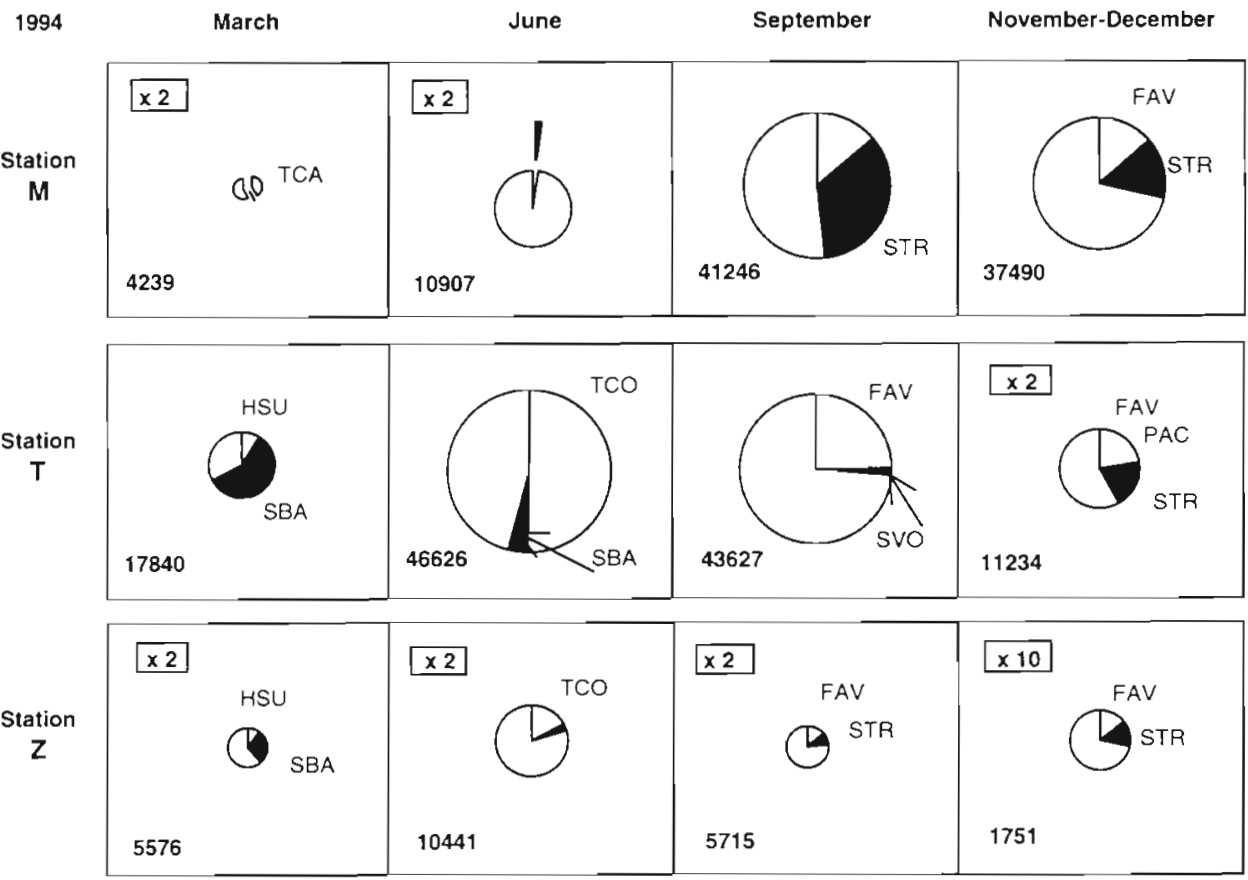

equally explain the presence of $S$. triophtalma at $\operatorname{Stn} Z$ and its practical absence at the other station in the lagoon (Stn T). Tintinnid and rotifer biomasses

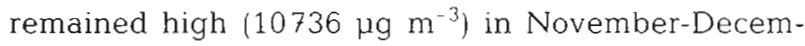
ber.

The change in biomass throughout the year was different inside the lagoon. On the one hand, whatever the season, biomass values at $\operatorname{Stn} \mathrm{Z}$ in the shellfishculture zone were approximately 10 times less than those at Stn T. This large difference may be caused by the trophic pressure from the cultured shellfish and their epifauna. Such a pressure is exerted both on the phytoplankton biomass, thus reducing available food resources in appropriate size fractions (even when living food items are rejected by the filtering mechanism of larger predators, the probability of survival of the former remains reduced), and directly on the tintinnids and rotifers themselves. On the other hand, biomasses at Stn $\mathrm{T}$ rose to $12015 \mu \mathrm{g} \mathrm{m}^{-3}$ in March in conjunction with a high biomass of the rotifer Synchaeta baltica in June when the Tintinnopsis corniger outburst produced the highest biomass value measured in 1994 (25215 $\mu \mathrm{g} \mathrm{m}^{-3}$ ), and finally in September (11495 $\mu \mathrm{g}$ $\mathrm{m}^{-3}$ ) with the high growth of the tintinnids Favella spp.

Thus, important demographic movements were very localised in space and time. Tintinnids and rotifers constitute an abundance structure which may characterise a given site at a given time. Such organisation, supported synthetically by an ordination of biomass data set crossing taxa and samples, can be related to their environment.

\section{Structural diversity of tintinnid and rotifer assemblages}

The factorial correspondence analysis of taxonomic biomasses sums up to an inertia of 2.638 . Independently from the image quality in the ordination space, the horseshoe disposition (Guttman effect) of projected points on several factorial biplot displays suggested a correlation between the ordination factors. Therefore the gradient structure in the space formed by 2 factors (or axes) F1 and F2 could be explained by $58 \%$ of the total inertia.

Samples from the seaside Stn M (M1 to M4, Fig. 3a) clearly show less dispersion than the samples collected in the lagoon ( $\mathrm{T} 1$ to $\mathrm{T} 4$ and $\mathrm{Z} 1$ to $\mathrm{Z} 4$ ). The tintinnid and rotifer biomass distributions in the lagoon fluctuated to a greater extent than they did at the seaside. The M3 and $\mathrm{T} 1$ samples and the $\mathrm{T} 1$ and $\mathrm{T} 2$ samples contributed to define respectively the factors $F 1$ and $F 2$, their absolute contribution values being more than $35 \%$ of the total inertia. The axis F1 represented a geographical gradient (sea-lagoon) and the axis F2 a gradient corresponding to the thermal periods (cold-warm periods). In the ordination space, the lagoon samples T3, T4, Z4 and especially Z3 were closed to those collected at the seaside, their position could be related to the coastal water input via the Canaux de Sète by the action of both the tidal movements and the prevailing winds.

With their absolute contribution values greater than $25 \%$, Synchaeta baltica (SBA) and S. triophtalma (STR) 

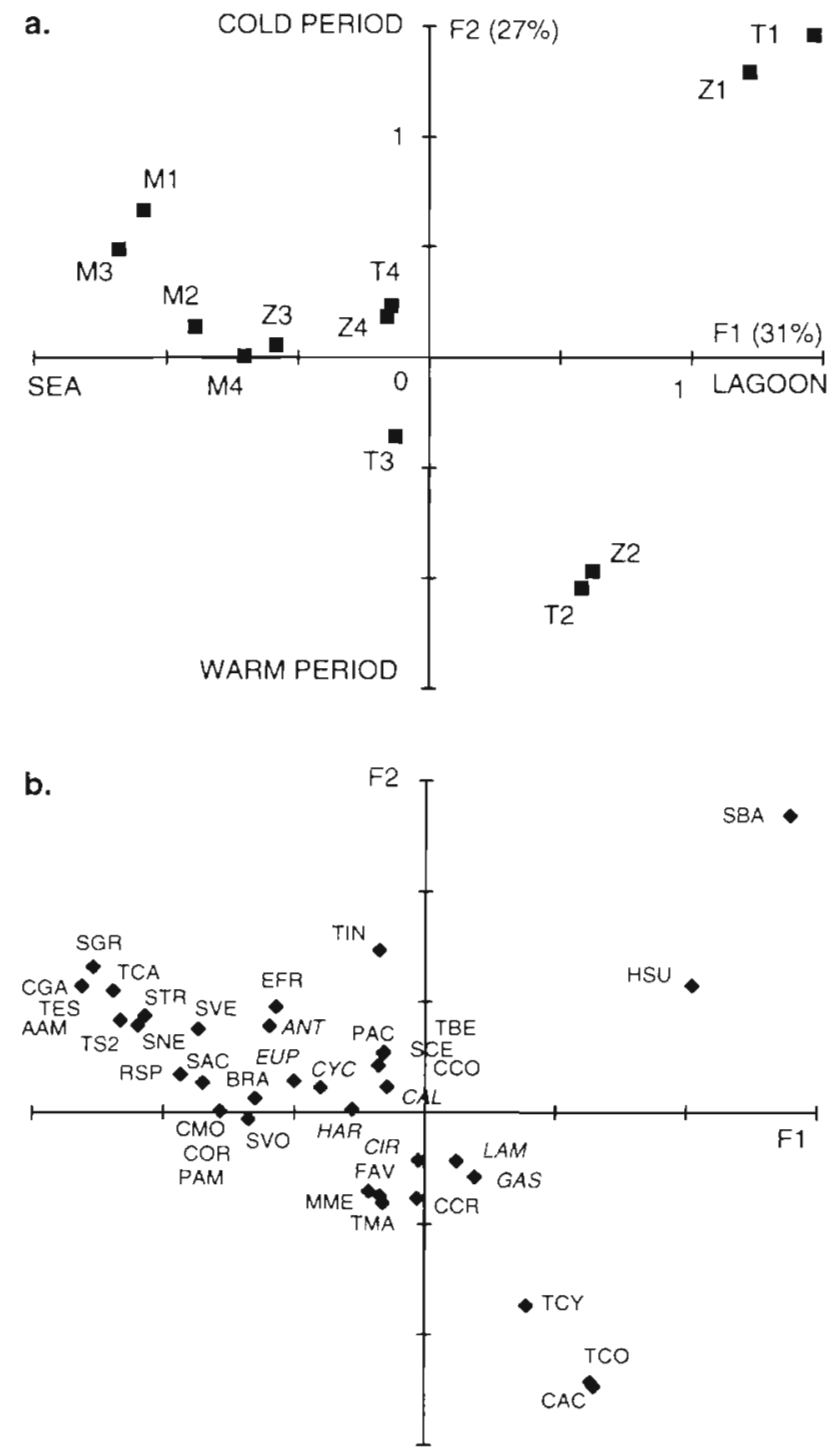

Fig. 3. Biplot display (axes F1 and F2, shown with their respective percentage of explained inertia) issued from factorial correspondence analysis of taxa biomasses. (a) Samples ( $T, Z, M$ : stations; 1 to 4 : sampling periods) displayed along geographic and thermal gradients; (b) taxa displayed in their preferential environment. See Table 1 for explanation of identity codes. Codes in italics correspond to natuplii and meroplankton. Codes shown without associated symbols are for hidden plots

defined the axis F1, and Tintinnopsis corniger (TCO) and S. baltica the axis F2 (Fig. 3b). The double definition of an axis by the same modality (e.g. taxon) reflected the Guttmann effect previously mentioned SBA and TCO were plotted in the part of the ordination space which represented the lagoon, while in versely STR was found towards the sea pole. The position of STR was due to a population bloom in special environmental conditions at Stn M (M3), e.g. low salinity at the seaside ( $30-34$ vs usual $36-37.5)$. This coastal feature was valid for the 1994 survey, but probably could not be generalised for SBA, a characteristically cold season species in the lagoon. Low biomass populations tended to occur either in the coastal waters (CMO, CGA, COR, PAM, SAC, SGR, TES) or in the lagoon (CAC, CCR, MME, PAC, TBE, BRA, CCO, SCE) except for Helicostomella subulata (HSU) which showed much higher biomass in the lagoon. The position of the taxa on the biplot display depended on the sampling periods in which they were available. By their occurrence at all the stations and their intermediate disposition in the ordination space, Favella spp. (FAV). Tintinnopsis campanula (TCA), S. vorax (SVO) and Trichocerca marina (TMA) appear to have been opportunist populations in the assemblages. However, FAV and TMA populations developed better inside the lagoon, while TCA and SVO had previlent biomasses at the seaside. The analysis positioned the taxa in their preferential environment and illustrated the fluctuation trends of populations according to the sampling periods and to the stations. Similar features were found with the other microzooplankton components (italicised codes, Fig. 3b) considered as additional observations in the analysis. Mollusk larvae (LAM, GAS) and most cirriped nauplii (CIR) occurred inside the lagoon and in warm periods, while anthozoan larvae (ANT) and euphausiacean nauplii (EUP) appeared only at the seaside in colder periods. Copepod nauplii (CAL, CYC, HAR), which occupied an intermediate position in the biplot display, increased their biomass towards the fall, especially at Stns $M$ and $T$. The biomass ordination of the net collected microzooplankton shows its structural diversity in the pelagic biocoenosis. Such an organisation may result from relationships between the environment and the populations and between the populations themselves. The following analysis tries to look for consistent links between these.

\section{Relationships between populations and environment}

Relationships between environmental variables and microzooplankton on the one hand and those between the different populations on the other can be simply measured by the Pearson correlation coefficient, applied to the daily samples collected at each station (Table 2) Significant correlations were found more often at Stn $M$ than at Stns $T$ and $Z$. This seems to indicate more selective conditions in the lagoon. Relationships of tintinnids and rotifers with environmental variables such as the water temperature (Tem) and the salinity (Sal) differed according to the populations and the stations. Within the value ranges observed in the Etang de Thau (see 'Envi- 
Table 2. Significant correlations ( $r$ ) between the environmental parameters (Tem: temperature; Sal: salinity) and tintinnid and rotifer populations (alphabetical codes, see Table 1 for explanations), between pairs of these populations, and between the tintinnid and rotifer populations and picophytoplankton (Pic; Ost: Ostreococcus tauri), bacterioplankton (Bac; Cya: cyanobacteria) and mesozooplankton (31: Sagitta minima, 56: Paracalanus parvus, 73: Acartia margalefi, 89: Oithona nana, 97: Euterpina acutifrons, 99: Microsetella norvegica, 108: Oikopleura dioica, 117: Phoronis, 122: spionid larvae, 123: capitellid larvae, 162: Ciona larvae). df: degrees of freedom

\begin{tabular}{|c|c|c|c|c|c|c|c|c|c|c|c|c|c|}
\hline \multirow{2}{*}{$\begin{array}{l}\text { Relation- } \\
\text { ships }\end{array}$} & \multicolumn{2}{|c|}{ Stn M } & \multicolumn{2}{|c|}{ Stn $T$} & \multicolumn{2}{|c|}{ Stn Z } & \multirow{2}{*}{$\begin{array}{l}\text { Relation- } \\
\text { ships }\end{array}$} & \multicolumn{2}{|c|}{$\operatorname{Stn} M$} & \multicolumn{2}{|c|}{ Stn $\Upsilon$} & \multicolumn{2}{|c|}{ Stn Z } \\
\hline & $r$ & $\mathrm{df}$ & $\Gamma$ & $d f$ & r & $\mathrm{df}$ & & $r$ & $\mathrm{df}$ & $r$ & $\mathrm{df}$ & $r$ & $\mathrm{df}$ \\
\hline Tem-FAV & -0.45 & 13 & & & & & CAL-FAV & 0.54 & 13 & & & & \\
\hline Tem-TCY & & & & & -0.65 & 10 & CAL-STR & & & -0.52 & 15 & & \\
\hline Tem-TCO & & & 0.72 & 9 & 0.63 & 8 & CAL-SBA & & & 0.39 & 18 & 0.91 & 14 \\
\hline Tem-SBA & & & -0.43 & 18 & & & CAL-SVO & 0.62 & 12 & & & & \\
\hline Sal-FAV & & & 0.46 & 14 & & & CAL-TMA & & & & & 0.47 & 12 \\
\hline Sal-TCY & & & & & -0.67 & 10 & CYC-FAV & & & 0.46 & 14 & & \\
\hline Sal-TCA & -0.67 & 17 & & & & & CYC-EFR & 0.63 & 8 & & & & \\
\hline Sal-TCO & & & & & -0.83 & 8 & CYC-TCY & & & & & -0.51 & 10 \\
\hline Sal-TS2 & -0.65 & 8 & & & & & CYC-TCO & & & -0.53 & 9 & & \\
\hline Sal-STR & -0.57 & 13 & -0.45 & 15 & & & CYC-TS2 & 0.72 & 8 & & & & \\
\hline Sal-SBA & & & -0.45 & 18 & & & CYC-STR & 0.76 & 13 & & & & \\
\hline Sal-SVO & & & 0.47 & 13 & & & CYC-TMA & & & & & 0.72 & 12 \\
\hline Pic-TCO & & & -0.67 & 9 & & & HAR-RSP & 0.86 & 8 & & & & \\
\hline Pic-TS2 & 0.74 & 8 & & & & & EUP-FAV & 0.58 & 8 & & & & \\
\hline PiC-STR & 0.78 & 13 & & & 0.41 & 18 & EUP-TCA & -0.58 & 10 & & & & \\
\hline Pic-SVO & & & & & 0.56 & 14 & & & & & & & \\
\hline Ost-SVE & 0.49 & 12 & & & & & FAV-31 & 0.94 & 8 & & & & \\
\hline Ost-TCO & & & -0.59 & 9 & & & FAV -73 & 0.78 & 9 & & & & \\
\hline Ost-TS2 & 0.60 & 8 & & & & & FAV-123 & & & & & 0.67 & 9 \\
\hline Ost-STR & 0.60 & 13 & & & 0.44 & 18 & TCA-89 & -0.40 & 17 & & & & \\
\hline Ost-SVO & & & & & 0.54 & 14 & TCA -97 & -0.50 & 16 & & & & \\
\hline $\mathrm{Bac}-\mathrm{TS} 2$ & 0.60 & 8 & & & & & $\mathrm{TCO}-73$ & & & 0.52 & 9 & 0.71 & 8 \\
\hline Bac-STR & 0.52 & 13 & & & & & $\mathrm{TCO}-97$ & & & 0.61 & 9 & & \\
\hline $\mathrm{Bac}-\mathrm{SBA}$ & & & -0.40 & 18 & & & TCO-108 & & & & & 0.64 & 8 \\
\hline Bac-TMA & -0.56 & 9 & & & & & TS2-97 & -0.68 & 8 & & & & \\
\hline Cya-EFR & 0.65 & 8 & & & & & HSU-117 & & & 0.87 & 9 & & \\
\hline Cya-STR & 0.52 & 13 & & & & & HSU-162 & & & 0.81 & 13 & & \\
\hline & & & & & & & RSP-56 & 0.57 & 8 & & & & \\
\hline FAV-STR & & & & & 0.92 & 13 & RSP-108 & 0.86 & 8 & & & & \\
\hline FAV-SVO & 0.99 & 12 & & & & & RSP-122 & 0.69 & 8 & & & & \\
\hline TCY-STR & & & & & 0.68 & 10 & STR-99 & 0.55 & 12 & & & & \\
\hline TS2-STR & 0.77 & 8 & & & & & STR-123 & & & & & 0.48 & 13 \\
\hline CIR-FAV & 0.73 & 9 & & & & & $\mathrm{SBA}-108$ & & & -0.44 & 18 & & \\
\hline CIR-TCY & & & 0.70 & 8 & & & SBA-117 & & & 0.67 & 10 & & \\
\hline CIR-TIN & & & 0.66 & 9 & & & SVO-73 & 0.77 & 8 & & & & \\
\hline CIR-STR & & & & & 0.50 & 17 & TMA-73 & & & 0.74 & 12 & & \\
\hline CIR-SVO & 0.73 & 9 & & & & & TMA- 97 & & & 0.79 & 12 & & \\
\hline GAS-TCO & & & 0.56 & 9 & & & TMA-108 & 0.61 & 9 & & & & \\
\hline LAM-TMA & 0.90 & 9 & & & & & TMA-122 & 0.77 & 9 & & & & \\
\hline
\end{tabular}

ronment and forcing factors'), these variables were linked to populations in different ways, e.g

- Favella spp. populations (FAV) may develop well in low temperature (negative correlation, Stn M) and in high salinity (positive correlation, Stn T);

Tintinnopsis cylindrica (TCY, Stn Z) as well as Synchaeta baltica (SBA, Stn T) occurred in low temperature and low salinity conditions inside the lagoon;

- Tintinnopsis corniger (TCO) permitted warmer waters with high salinity (Stn $\mathrm{T}$ );

- Tintinnopsis campanula (TCA) and Tintinnopsis sp.2 (TS2) populations at Stn M and Synchaeta trioph- talma (STR) at Stns $M$ and $T$ were found in periods of relatively low salinity, while $S$. vorax (SVO) seemed to prefer a high salinity environment.

Biological factors included cellular concentrations of picophytoplankton (Pic; and Ost: Ostreococcus tauri), of bacterioplankton (Bac; and Cya: cyanobacteria) and of other net collected zooplankton populations. Positive correlations between different populations did not only mean their simultaneous occurrence at the site, such correlations may also reflect either the same requirements for physical and chemical conditions and food availability, or the backward effect from popula- 
tion mutual controls. Negative correlations might suggest predation pressure or the direct control of one population over another.

Many positive correlations between tintinnid and rotifer populations and picophytoplankton as well as bacterioplankton related generally their simultaneous occurrence in the water column (Pic-TS2, Pic-STR, PicSVO, Ost-SVE, Ost-TS2, Ost-STR, Ost-SVO, Bac-TS2, Bac-STR, Cya-EFR, Cya-STR). In some cases these positive correlations may indicate trophic relationships without a demographic impact on the prey populations, e.g. as for the couple cyanobacteria-Eutintinaus fraknoii (Cya-EFR) at Stn M; Bernard \& Rassoulzadegan (1993) stated that some tintinnids (Eutintinnus sp. and Tintinnopsis beroidea) fed exclusively on cyanobacteria. The positive correlation between the couple bacterioplankton-Synchaeta triophtalma (Bac-STR, Stn $M$ ) could have matched the trophic design from Dolan \& Gallegos (1991): the predation of Synchaeta spp. reduced the stocks of heterotrophic microflagellates and by this, reduced their grazing pressure on bacteria. The only negative correlation, Ostreococcus tauri- $T$. corniger (Ost-TCO) at Stn $T$, suggested that this tintinnid might graze on the picophytoplankton. Moreover, negative correlations between tintinnids and rotifers and other zooplankton populations may signify prey-predator relationships with demographic control, e.g.

- Within the microzooplankton assemblages: at the seaside, between euphausiacean larvae and Tintinnopsis campanula (EUP-TCA); in the lagoon, between cyclopoid nauplii and $T$ corniger (CYC-TCO) or $T$. cylindrica (CYC-TCY), between calanoid nauplii and Synchaeta triophtalma (CAL-STR).

- Within the mesozooplankton components: at the seaside, between the cyclopoid Oithona nana and Tintinnopsis campanula (TCA-89) and between the harpacticoid Euterpina acutifrons and $T$ campanula (TCA-97) or Tintinnopsis sp.2 (TS2-97); in the lagoon, between appendicularian Oikopleura dioica and Synchaeta baltica (SBA-108).

The simultaneous occurrence (positive correlations) of tintinnid and rotifer populations with mesozooplankton populations (numerical codes in Table 2) suggests that the former constitute potential food resources for the latter, as has been proposed by many authors (Koehl \& Strikler 1981, Robertson 1983, Stoecker \& Sanders 1985, Williamson \& Butler 1986 , Ayukai 1987, Alvarez 1988, Egloff 1988, Urban et al. 1992, White \& Roman 1992, Pinel-Alloul 1995). The positive correlations with naupliar stages (CAL, CYC, HAR, EUP, CIR), or with veligers (GAS, LAM) and other meroplankton (larvae), such as Phoronis (117), spionids (122), capitellids (123) and Ciona (162), should likely signify a dependence on the environmental conditions (e.g. spring and autumn periods) and on the food availability (microflagellates, dinophyceans, diatoms, ciliates). Biomass estimations of these larval stages figured in a range of 450 to $13500 \mu \mathrm{g} \mathrm{m}^{-3}$ (average $8872 \mu \mathrm{g} \mathrm{m}^{-3}$ ) for the nauplii, 500 to $25000 \mathrm{\mu g} \mathrm{m}^{-3}$ (average $3154 \mu \mathrm{g}$ $\mathrm{m}^{-3}$ ) for the veligers and 500 to $17600 \mathrm{\mu g} \mathrm{m}^{-3}$ (average $4667 \mu \mathrm{g} \mathrm{m}^{-3}$ ) for the meroplankton.

Correlation analysis was conducted to establish the trophic function of the tintinnid and rotifer populations, which could be examined through microscope observations and literature data. It is obvious that the food diet of an organism cannot be fully defined by simple microscope observations. For instance, diatom frustules or some dinophyceans are more easily identified than other phytoplankton cells which constitute a larger fraction of food for tintinnids and rotifers. Microscope preparations show the occurrence of dinophyceans (Fig. 4a, b), of diatoms, and of other tintinnids of smaller sizes, such as Tintinnopsis sp. in Favella cells during the 1994 survey. A tintinnid (Tintinnopsis sp.) was observed in the body of a Synchaeta vorax predator (Fig. 4c), and a mastax of the small S. cecilia was found in another individual. The stomach of a $S$. vorax individual from the November-December period was occupied by a dinophycean (Prorocentrum sp.) as well as a diatom (Oestrupia sp.) (Fig. 4d). The above feeding behaviour can switch to cannibalism, if the prey is smaller than the predator; such an event was observed twice with living plankton.

\section{DISCUSSION AND CONCLUSION}

Estimations of the tintinnid and rotifer abundances in the Etang de Thau and averaged over the 2 stations and all the sampling periods were, respectively, 75700 ind. $\mathrm{m}^{-3}\left(5200 \mu \mathrm{g} \mathrm{m}^{-3}\right)$ and 3530 ind. $\mathrm{m}^{-3}\left(2240 \mu \mathrm{g} \mathrm{m} \mathrm{m}^{-3}\right)$. These values were less than those from other sites: Gulf of Marseille (Travers \& Travers 1971, net and Utermöhl's methods), Villefranche Bay (Rassoulzadegan 1979, $50 \mu \mathrm{m}$ mesh net). However, in contrast, they were higher than in the eastern areas, as in Lebanese coastal waters (Abboud-Abi Saab 1989, $50 \mu \mathrm{m}$ mesh net). North Irish Sea tintinnid densities reported by Graziano (1989) fluctuated from 1 to 729000 ind. $\mathrm{l}^{-1}$ (Nansen-Peterson sampler). Moreover, density estimations of aloricate oligotrichs in the Etang de Thau may reach 6 to 18 times that of the tintinnids. Obviously this group needed more appropriate investigations. Rotiferian densities were generally less than those collected in 70 to $90 \mu \mathrm{m}$ nets by Heinbokel et al. (1988), Ferrari et al. (1982), and Hernroth (1983), the Etang de Thau being more open to sea waters. The biomass analysis shows 2 factors which affected the assemblage structure of the tintinnids and rotifers: the geo- 
a

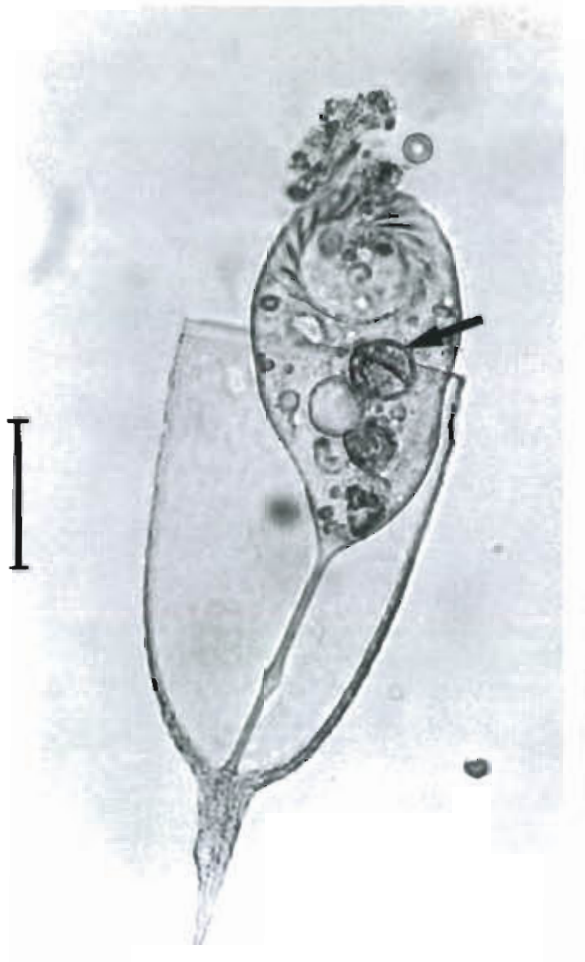

b

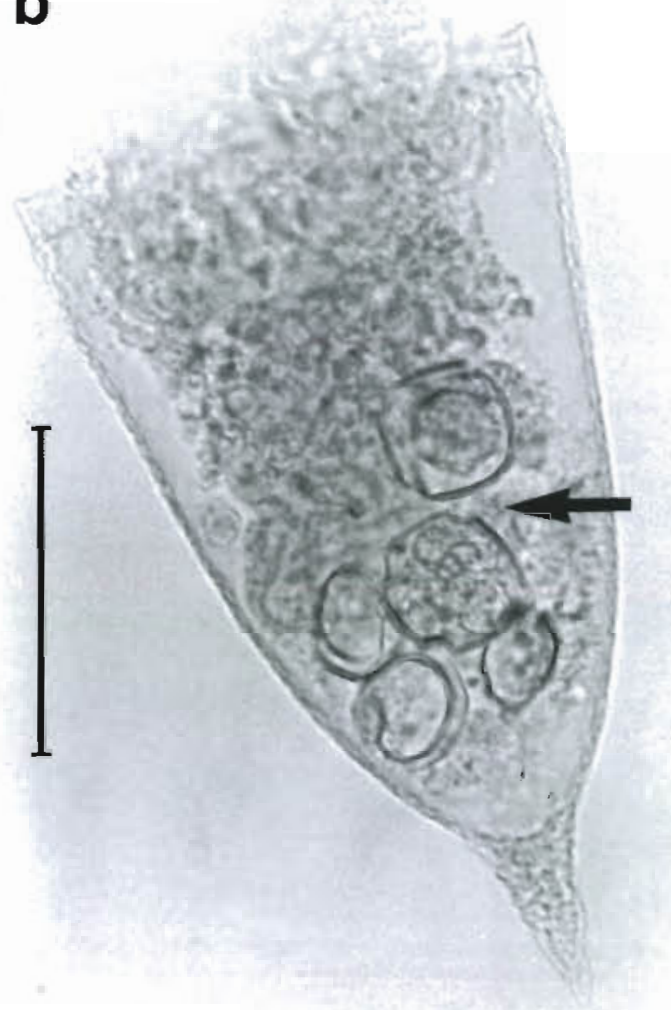

Fig. 4. Tintinnids and rotifers showing ingested organisms. For all plots, scale bar $=50 \mu \mathrm{m}$. (a) Living Favella individual with dinophycean cells (arrow); (b) a fixed Favella individual with dinophycean cells (arrow); (c) a tintinnid individual (Tintınnopsis sp.) (arrow) inside Synchaeta vorax; and (d) a diatom (Oestrupia sp.) cell (right arrow) and a dinophycean (Prorocentrum sp.) cell (left arrow) inside $S$. vorax
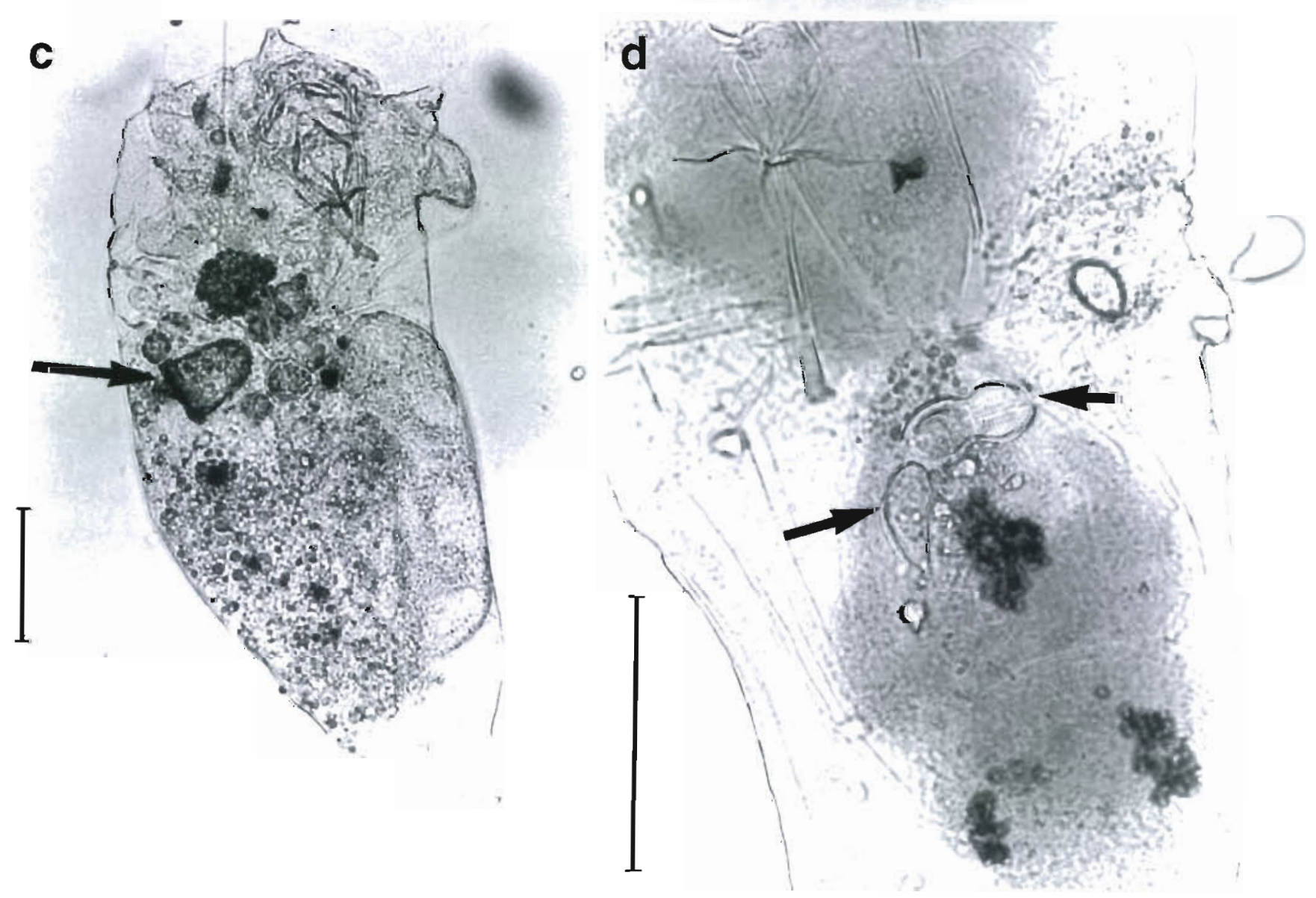
graphical position and the thermal period. The geographical position integrated on the one hand the tidal influence (maximum tide amplitude: 0.05 to $0.07 \mathrm{~m}$ ) as a lagoon-sea gradient, and on the other hand the force and duration of prevailing winds. The effect of the thermal period constituted another gradient which resulted both from population development cycles and from environmental constraints (e.g. temperature, salinity). Large hydrological variability linked to meteorological conditions may impose important demographic outbursts and declines in the pelagic biocoenosis in an almost unforeseen way. Spatial and temporal fluctuations of tintinnid and rotifer populations inside the lagoon were shown to be governed by the trophic pressure of shells and epifauna from the shellfish-culture installations and by the sea input influence on Stn Z. It would be obvious to include the inter-population relationships (e.g. predation, competition) among the multiple mechanisms dffecting the assemblage organisation. Such features could be replicated in term of densities analyses, since they concern taxocoenoses without large differences in their size distributions (Rougier \& Lam-Hoai unpubl. report 1995).

The outlined relationships between populations and environment were coherent with the previously described structural diversity. They underlined that salinity was a structuring factor at the seaside, and that temperature was an additional one inside the lagoon, although each of them could exert their influence locally on other processes (reproduction, growth).

Trophic function of tintinnids and rotifers in the pelagic biocoenosis appeared to be important. They are either predators or competitors as well as preys, as indicated by correlation analysis and by the occurrence of nanoplankton in Favella cells and of tintinnids inside Synchaeta individuals. Our observed data agree with trophic information given by many authors: tintinnids and rotifers are trophic links between net microzooplankton and mesozooplankton populations. In the literature (Hollibaugh et al. 1980, Rassoulzadegan \& Etienne 1981, Burkill 1982, Andersen \& Sorensen 1986, Verity 1986, Fenchel 1987, Bernard \& Rassoulzadegan 1993, Laval-Peuto 1993), tintinnids use a large spectrum of food resources such as organic matters, bacteria, pico- and nanoplankton, maximum food particle size being 41 to $46 \%$ of the consumer oral diameter (Spittler 1973). Some tintinnids preferably select dinoflagellates (Stoecker et al. 1981). Rassoulzadegan (1982) observed that growth was greater when they fed on microflagellates. Conover (1982) reported that tintinnids ingested nanoplankton with daily rations from 0.5 to 3 times their own biomass. The negative correlation between Ostreococcus tauri and Tintinnopsis corniger observed at Stn $\mathrm{T}$ leads to the following question: does $O$. tauri, the smallest eucaryote cell (Courties et al. 1994), have the same trophic function towards some tintinnid populations inside the lagoon as cyanobacteria has with Eutintinnus fraknoii at the seaside? Among the ciliates, aloricate oligotrichs may have a food diet similar to the tintinnids since they consume particles in the size range of 0.5 to $10 \mu \mathrm{m}$ (Rassoulzadegan et al. 1988). But within the same size, these naked ciliates would feed on smaller prey ( $M$. Peuto-Moreau pers. comm. 1997). The rotifer genus Synchaeta, the main representative genus found in the Etang de Thau, were micropredators, preferring microflagellates of the 10 to $20 \mu \mathrm{m}$ size range (Pourriot. 1977, Dolan \& Gallegos 1991, Pont 1995).

Tintinnids and rotifers may be in competition with each other for the 10 to $20 \mu \mathrm{m}$ phytoflagellates. Taniguchi \& Kawakami (1985) have cultivated the tintinnid Favella taraikaensis with Prorocentrum as the oniy source of food, and in fact this dinophycean was also consumed by the rotifer Synchaeta vorax in the Etang de Thau (see Fig. 4d). The competition could explain the scarcity of $S$. triophtalma in September at Stn $I$, while this rotifer was largely dominant at the other 2 stations; their tintinnid competitors, Favella, were 15 times more abundant at Stn T. Hernroth (1983) attributed the decline of rotifers at Fjord Gullmar in Norway to the competition for food with tintinnids. Moreover, compared to their competitors, such as ciliates and copepods, which may grow at lower concentrations of food (Heinbokel et al. 1988) rotifers would be penalised. Tintinnids are also in competition with copepods, because the latter can consume small particles through one of their modes of filtration (passive type), according to Pourriot \& Lescher-Moutoué (1983). Tintinnids, as purifying agents, are far more efficient consumers of very small food particles (Rassoulzadegan 1982), especially since their biomass could have similar magnitude to the copepods' (June Stn T)

Copepods are the main predators of tintinnids (Koehl \& Strikler 1981, Robertson 1983, Stoecker \& Sanders 1985, Ayukai 1987. Alvarez 1988, Egloff 1988, Urban et al. 1992, White \& Roman 1992). According to Gifford (1991), calanids may consume phytoplankton as well as zooplankton, and this ability would mean an adaptation to changes in food resources. Stoecker \& Egloff (1987) noted that Acartia tonsa produces 25\% more eggs when they are fed with ciliates and rotifers than when they are fed with the same concentration of phytoplankton. Copepods, the main predators of tintinnids, may also consume rotifers (Egloff 1988, Pinel-Alloul 1995). As far as the predation on rotifers is concerned, Synchaetae aloricate species are quite available food items for marine calanids (Williamson \& Butler 1986, Egloff 1988, Pinel-Alloul 1995). These data permitted the explanation of prey-predator rela- 
tionships implied by correlations with mesozooplankton found in this study (Table 2).

Potential filtration may illustrate the trophic activity of tintinnids and rotifers in the ecosystem. Taniguchi \& Kawakami (1985) indicated tintinnid filtration rates of 0.4 to $14.5 \mu \mathrm{l}$ ind. $^{-1} \mathrm{~h}^{-1}$; and $\mathrm{C}$. Rougier (pers. comm. 1995) compiled rates according to the size categories from the previous authors' data and also from Rassoulzadegan \& Etienne (1981) and found a range of 0.1 to $3.5 \mu \mathrm{l}$ ind. ${ }^{-1} \mathrm{~h}^{-1}$ Rotifer filtration rates have been estimated to be 0.1 to $4 \mu \mathrm{l}$ ind. ${ }^{-1} \mathrm{~h}^{-1}$ by Pont (1995), 8.7 to $17.8 \mu \mathrm{l}$ ind $^{-1} \mathrm{~h}^{-1}$ by Dolan \& Gallegos (1991) and 2 to $18 \mu$ ind..$^{-1} \mathrm{~h}^{-1}$ by Egloff (1988). These rates appear to be quite low compared to other microzooplankton ones: 0.47 to $1.99 \mathrm{ml}$ ind $\mathrm{d}^{-1} \mathrm{~d}^{-1}$ for copepod nauplii grazing on phytoplankton (White \& Roman 1992), 0.11 to $0.56 \mathrm{ml}$ ind.$^{-1} \mathrm{~d}^{-1}$ for nauplii preying on ciliates (Dolan 1991), or 0.1 to $4.1 \mathrm{ml}$ ind $^{-1}$ $\mathrm{d}^{-1}$ for mollusk larvae feeding on diatoms and dinoflagellates (White \& Roman 1992). As the average abundances in the Etang de Thau (throughout the sampling periods and for all stations) were estimated to be $75700 \mathrm{ind} . \mathrm{m}^{-3}$ for the tintinnids and 3530 ind. $\mathrm{m}^{-3}$ for the rotifers, these rates calculated at a potential filtration rate on the order of $10 \mathrm{l} \mathrm{d}^{-1}$ for the populations present in $1 \mathrm{~m}^{3}$ of water. Although the densities in the lagoon approximated a ratio of 8 tintinnids (dominant components) or rotifers for each individual of the mesozooplankton, the filtration rates of the latter, by similar estimations, would be 30 to 50 higher than those of the tintinnids and rotifers. Nevertheless, with a high metabolism, tintinnids could have a matter recycling rate by unit weight larger than that of the copepods, their daily ration per body volume being 6 times higher. These data help to gauge the relative impact of the microzooplankton and the mesozooplankton in the pelagic ecosystem.

The mode of reproduction (division, parthenogenesis) and the short generation time, $48 \mathrm{~h}$ for the tintinnids (Rassoulzadegan 1982) and from 4 to 2 d within the temperature range of 10 to $22^{\circ} \mathrm{C}$ for the rotifers (Pourriot \& Deluzarches 1971), permit these 2 groups to promptly colonise any habitat. Moreover, their capacity to produce resting eggs (rotifers) and cysts (tintinnids) prevailed in a shallow environment such as a coastal lagoon. Light, temperature and oxygenation were determining factors for the hatching of eggs and cysts (Pourriot et al. 1977. Hernroth 1983, Kamiyama et al. 1995). These conditions could explain the tintinnid and rotifer development in the lagoon during March. Favella serrata cysts had been found in the site by September and November-December ( $2 \%$ of the observed individuals), as well as Synchaeta vorax (SVO) resting eggs. Such settlement needed abundant and available food resources.
From the data obtained during 1994, the tintinnid and rotifer populations, of which neither the ecology nor the life cycle has yet been studied in the Etang de Thau, seem to be governed by environmental factors (climatic as well as hydrological events). These are the prevalent 'forcing' factors of the ecosystem which control the spatio-temporal repartition of the biomass of such taxocoenoses. A structural diversity results from this which is revealed by our data analysis. Moreover, the function of these 2 microzooplankton groups, in relation to the other zooplankton components, has been pointed out in a lagoon system.

Acknowledgements. This study was supported by the PNOC/OXYTHAU program and conducted with the collaboration of IFREMER-University of Montpellier II URM5. The authors thank CNRS-University of Montpellier II UMR 5556 colleagues and technical staff for their valuable contributions. Meteorological data were provided by B. Bibent, and cytofluorimeter data by $\mathrm{C}$. Courties. The authors are also indebted to Dr M. Peuto-Moreau (Université de Nice) and Dr R. Pourriot (CNRS-Université de Paris VI) for identifying, respectively, tintinnids and rotifers, and for their advice. Many thanks to Dr A. Vaquer for phytoplankton identification and the aloricate oligotrich density estimations. The manuscript was greatly improved by comments and suggestions of the reviewers

\section{LITERATURE CITED}

Abboud-Abi Saab M (1989) Distributıon and ecology of tintinnids in the plankton of Lebanese coastal waters (eastern Mediterranean). J Plankton Res 1 1(2)203-222

Alvarez JN (1988) Populations dynamics and feeding habits of the chaetognaths Sagitta elegans Verril and S. setosa Muller in Manx waters, north Irish Sea. PhD thesis, University of Liverpoo]

Amanieu M, Lasserre G (1982) Organisation et évelution des peuplements lagunaires. Oceanol Act Proc lnt Symp Caastal Lagoons Bordeaux 1981:201-213

Andersen P, Sorensen HM (1986) Populations dynamics and trophic coupling in pelagic microorganisms in eutrophic coastal waters. Mar Ecol Prog Ser 33:99-109

Arndt $H$, Schröder C, Schnese W (1990) Rotifers of the genus Synchaeta-an important component of the zooplankton in the coastal waters of the southern Baltic. Limnologica 21:233-235

Ayukai T (1987) Predation by Acartia clausi (Copepoda: Calanoidal on two species of tintinnids. Mar Microb Food Webs 2(1):45-52

Balech E (1959) Tintinnoinea del Mediterraneo. Trab Inst Esp Oceanogr 28:1-88

Bernard C, Rassoulzadegan F (1993) The role of picoplankton (cyanobacteria and plastidic picoflagellates) in the diet of tintinnids. J Plankton Res 15(4):361-373

Berzins B (1960) Rotatorla I. Synchaetıdae. Cons Int Explor Mer Identif Leafl 84:1-57

Burkill PH. (1982) Ciliates and other microplankton components of a nearshore food-web: standing stocks and production processes. Ann Inst Oceanogr 58:335-350

Conover RJ (1982) Interrelations between microzooplankton and other plankton organisms. Ann Inst Oceanogr 58(5): $31-46$

Courties C, Vaquer A, Troussellier M, Lautier J, Chrétiennot- 
Dinet MJ, Neveux J, Machado C (1994) Smallest eukariotic organism. Nature 370:255

Dolan JR (1991) Microphagous cillates in mesohaline Chesapeake Bay waters: estimates of growth rates and consumption by copepods. Mar Biol 111:303-309

Dolan JR, Gallegos CL (1991) Trophic coupling of rotifers, microflagellates, and bacteria during fall months in the Rhode River Estuary. Mar. Ecol Prog Ser 77:147-156

Dussart B (1965) Les différentes catégories de plancton. Hydrobiologia 26:72-74

Egloff DA (1988) Food and growth relations of the marine microzooplankter, Synchaeta cecilia (Rotifera). Hydrobiologia 157:129-141

Fenchel T (1987) Ecology of protozoa. The biology of freeliving phagotrophic protists. Sci Tech Inc, Madison, WI

Ferrari l. Ceccherell vU, Mazzochi MG (1982) Structure du zooplancton dans deux lagunes du delta du Pô. Oceanol Acta Proc Int Symp Coastal Lagoons Bordeaux 1981. $293-302$

Gifford DJ (1991) The protozoan-metazoan trophic link in pelagics ecosystems. J Protozool 38:81-86

Graziano $C$ (1989) On the ecology of tintinnids (Ciliophora: Oligotrichida) in the North Irish Sea. Estual Cuast Shelf Sci 29:233-245

Heinbokel JF, Coste DW, Henderson KW, Tyler MA (1988) Reproduction rates and secondary production of three species of the rotifer genus Synchaeta in the estuarine Potomac River. J Plankton Res 10(4):659-674

Hernroth L (1983) Marine pelagic rotifers and tintinnidsimportant trophic links in the spring plankton community of the Gullmar Fjord, Sweden. J Plankton Res 5(6):835-846

Hollibaugh JT, Fuhman JA, Azam F (1980) Radioactively labeling of natural assemblages of bacterioplankton for use in trophic studies. Limnol Oceanogr 25:172-181

Hollowday ED (1949) A preliminary report on the Plymouth marine and brackish-water Rotifera. J Mar Biol Assoc UK 28:239-253

Jörgensen E (1924) Mediterranean Tintinnidae. Rept Danish Oceanograph Exped 1908-1910 to the Mediterranean and adjacent seas. 2 (biol.):1-110

Jouffre D (1989) Etude de I'organisation spatiale du zooplancton dans l'étang de Thau (France) et de l'influence des échanges entre la lagune et la mer. Thèse Doc, Univ Sci Tech Languedoc, Montpellier

Kamiyama T, Itakura S, Nagazakı K (1995) Effects of irradiance on excystment of tintinnids from marine sediments. J Oceanogr 51:615-618

Klugh HE (1970) Statistics: the essentials for research. John Wiley \& Sons Inc, New York

Koehl MAR, Strikler JR (1981) Copepod feeding currents food capture at low Reynolds number. Limnol Oceanogr 26:1062-1073

Kofoid CA, Campell AS (1939) Reports on the scientific results of the expedition to the Eastern Tropical Pacific. The Cilaata: the tintinnonea. Bull Mus Comp Zool 84:1-473

Koste W (1978) Rotatona. Die Rädertiere Mitteleuropas Gebrüder Borntraeger, Berlin

Lam-Hoai T (1985) Evolution saisonnière du zooplancton dans trois sites peu profonds de Thau, une lagune nordmóditerranéenne. Hydrobiologia 128:161-174

Lam-Hoai T (1991) Zooplankton counted by image analysis and size-frequency distributions in a coastal lagoon. Arch Hydrobiol 121(3):147-159

Lam-Hoai T, Amanieu M (1989) Structures spatiales et évolution salsonnière du zooplancton superficiel dans deux écosystèmes lagunaires nord-méditerranéens. Oceanol Acta 12(1):65-77
Lam-Hoai T, Gril C (1991) Biomasses et structures de taille du zooplancton hivernal dans une lagune nord-méditerranéenne. Cah Biol Mar 32:185-193

Laval-Peuto M (1993) Classe des Oligotrichea Bütschlii, 1987 Ordre des Tintinnida. In: Grasse P (ed) Traité de zoologie 2(2). Masson \& Cie, Paris

Laval-Peuto M, Brownlee DC (1986) Identification and systematics of the Tintinnina (Ciliophora): evaluation and suggestions for improvement. Ann Inst Océanogr Paris 62:69-84

Margalef R, Duran M (1953) Microplancton de Vigo, de octubre de 1951 a septiembre de 1952. Publ Inst Biol Apl Barc 13:5-78

Mathias P, Euzet L (1951) Sur les copépodes planctoniques de l'étang de Thau. Bull Soc Hist Nat Toulouse 86:184-188

Mathias P, Euzet L (1962) Le plancton du bassin de Thau (Etang des Eaux blanches). Natur Monspel Sér Zool 3: $7-27$

Mathias P. Tcherniakofsky P (1932) Etude sur l'étang de Thau. Bull Soc Centr Aquic Pèche 39(10-12):97-114

Millet B (1989) Fonctionnement hydrodynamique du bassin de Thau Validation écologique d'un modèle numérique de circulation (programme Ecothau). Oceanol Acta 12(1): $3 \overline{7}-4 \overline{6}$

Mullin MM (1969) Production of plankton in the ocean: the present status and problems. Oceanogr Mar Biol Annu Rev 7:293-314

Omori M, lkeda $T$ (1984) Methods in marine zooplankton ecology. John Wiley \& Sons, New York

Pinel-Alloul B (1995) Les invertébrés prédateurs du zooplancton. In: Pourriot R, Meybeck M (eds) Limnologie générale. Masson \& Cie, Paris, p 541-564

Pont D (1995) Le zooplancton herbivore dans les chaines alimentaires pélagiques. In: Pourriot R, Meybeck $M$ (eds) Limnologie générale. Masson \& Cie, Paris, p 515-540

Pourriot R (1977) Food and feeding habits of Rotufera. Arch Hydrobiol Beih Ergeb Limnol 8:243-260

Pourriot R, Champ P, Clément P, Rougier C (1977) Les influences de la lumière sur les Rotifères et le déterminisme de la reproduction. Bull Soc Zool Fr 101(5):923-926

Pourriot R. Deluzarches M (1971) Recherches sur la biologie des Rotifères. II. Influence de la température sur la durée du développement embryonnaire et post-embryonnaire. Ann Limnol 7:25-52

Pourriot R, Lescher-Moutoué F (1983) Problèmes de stratégies alimentaires chez le zooplancton d'eaux continentales Bull Soc Zool Fr 108(3):485-498

Rassoulzadegan F (1979) Evolution annuelle des Ciliés pélagiques en Méditerranée Nord occidentale. II Ciliés oligotriches, Tintinnides (Tintinnina). Invest Pesq 43:417-448

Rassoulzadegan F (1982) Le ròle fonctionnel du microzooplancton dans un écosystème méditerranéen. Thèse Doc, Univ P et $M$ Cume, Paris

Rassoulzadegan F, Etienne M (1981) Grazing rate of the tintinnid Stenosemella ventricosa (Clap and Lachm) Jörg on the spectrum of the naturally occurring particulate matter from a Mediterranean neritic area. Limnol Oceanogr $26: 258-270$

Rassoulzadegan F, Laval-Peuto M, Sheldon RW (1988) Partitioning of the food ration of marine culiates between picoand nanoplankton. Hydrobiologia 159:75-88

Remane A (1929) Tierwelt der Nord- und Ostsee. Rotatoria. In: Grimpe-Wagler (ed) VII (16), Leipzig

Robertson JR (1983) Predation by estuarine zooplankton on tintinnid ciliates. Estuar Coast Shelf Sci 16:27-36

Rougier C, Lam-Hoai I (in press) Biodiversity through two groups of microzooplankton in a coastal laçoon (Etang de Thau, France). Vie Milieu 
Rousselet CF (1909) The genus Synchaeta: a monographic study, with descriptions of five new species. JR Microsc Soc 1902:269-411

Spittler P (1973) Feeding experiments with tintinnids. Oikos 15(8): $128-132$

Stoecker D, Guillard RRL, Kavee RM (1981) Selective predation by Favella ehrenbergii (Tintinnina) on and among dinoflagellates. Biol Bull (Woods Hole) 160: $136-145$

Stoecker DK, Egloff DA (1987) Predation by Acartia tonsa Dana on planktonic ciliates and rotifers. J Exp Mar Biol Ecol 110:53-68

Stoecker DK, Sanders NK (1985) Differential grazing by Acartia tonsa on a dinoflagellate and a tintinnid. J Plankton Res $7(1): 85-100$

Taniguchi A, Kawakami A (1985) Feeding activity of a tintinnid ciliate Favella taraikaensis and its variability observed

This article was submitted to the editor in laboratory cultures. Mar Microb Food Webs 1:17-34

Travers A, Travers M (1971) Catalogue des Tintinnides (Ciliés oligotriches) récoltés dans le golfe de Marseille de 1962 à 1964. Téthys 2:639-646

Urban JL, McKenzie CH, Deibel D (1992) Seasonal differences in the content of Oikopleura vanhoetteni and Calanus finmarchicus faecal pellets: illustrations of zooplankton food web shifts in coastal Newfoundland Waters. Mar Ecol Prog Ser 84:255-264

Verity PG (1986) Growth rate of natural tintinnids populations in Narragansett Bay. Mar Ecol Prog Ser 29:117-126

White JR, Roman MR (1992) Seasonal study of grazing by metazoan zooplankton in the mesohaline Chesapeake Bay. Mar Ecol Prog Ser 86:251-261

Williamson CE, Butler NM (1986) Predation on rotifers by the suspension-feeding calanoid copepod Diaptomus pallidus. Limnol Oceanogr 31:393-402

Manuscript first received: June 27, 1996

Revised version accepted: April 7, 1997 